\title{
The Development of Readiness for the Educational Activities in Teachers of Higher Military Educational Institutions
}

\author{
Mykhailo Medvid ${ }^{1, *}$, Volodymyr Dem’yanyshyn ${ }^{1}$, Inna Chernichenko', \\ Volodymyr Honchar ${ }^{1}$ and Volodymyr Liutyi ${ }^{1}$ \\ ${ }^{1}$ National Academy of the National Guard of Ukraine, the Ukraine Defenders Square, 3, Kharkiv, 61001, Ukraine \\ *Corresponding author. Email: medvidmm@ukr.net
}

\begin{abstract}
The subject matter reflects the experience of the National Academy of the National Guard of Ukraine in teacher training. In addition, it displays the results of the pedagogical experiment on implementing the conditions for the development of readiness for the educational activities in teachers of higher military educational institutions and prospective teachers of military units. 230 teachers were involved in the experiment under the two postgraduate education programs. Program 1 aimed at improving pedagogical skills and the educational process while Program 2 focused on the foreign languages teaching methods. The updated pedagogical conditions for teaching under Program 1 comprised new content modules such as "Interactive teaching methods" and "Strategic communication in the educational process" and teaching a demo lesson, during the discussion of which the teacher must report to the staff of the department on the competencies he/she had gained upon the training and used them further when preparing and conducting this lesson. The new pedagogical conditions for studying Program 2 encompass the extension of the course duration; the application of modern technical tools in the learning process; the practical component implementation; increase and diversification of interactive teaching methods; involvement of foreign language teachers among native speakers and the use of information and technology forms of learning (distance learning).

According to the experiment results, the teachers of experimental groups revealed a higher level of readiness for educational activities.
\end{abstract}

Keywords: teachers advanced training, teacher training programs, readiness for educational activities of teachers, higher military educational institutions, National Academy of the National Guard of Ukraine

\section{INTRODUCTION}

Based on the definition of "teaching" [1], the teacher is a person whose activities are aimed at the formation of knowledge, professional competencies, worldview, development of intellectual and creative abilities, emotional, volitional and/or physical qualities of the students. During his/her formation as a teacher the novice develops such quality as readiness for educational activities. According to A. Rezanovich, readiness is interpreted as "the quality of a personality, which expresses his/her commitment to the activity, as well as the degree of assimilation of its elements, relevant social experience and the ability to use this experience in professional activities. Readiness can be represented as the integrity of elements: motivational readiness, theoretical readiness and practical readiness" [2]. Thus, we agree with this interpretation and use it in our study.
In their studies, S.M. Wilson and D.L. Ball [3], J.C. Duncheon and J. Muñoz [4], S.M. Khatuntseva [5], S.O. Sharaya [6], T.D. Fedirchyk [7] et al. focus on the infusion of the novice teacher to the professional and pedagogical activity as well as his/her formation.

One should note that it is difficult to assess the level of readiness for the educational activities in experienced teachers, just as it is not easy to conclude on the necessity of creating new conditions for the self-development of readiness in teachers in terms of educational activities.

It is also worth noting that despite the significant number of studies on building and developing teachers readiness for educational activities, there is a lack of works on the problem of training officers, prospective teachers with no degree in Pedagogy for higher military educational institutions (HMEIs), i.e. the problem we cover in the present paper.

One of the conditions for building and developing the teachers readiness for educational activities is his / her advanced training. 


\section{PROBLEMS AND METHODOLOGY}

The development of a system of the methodical work within the higher education institutions as a core of advanced training was studied by V.M. Moroz [8], V.V. Yegorova [9], M. Vanderburg, D. Stephens [10], M. Medvid, I. Chernichenko, Yu. Medvid, V. Dem'yanyshyn [11] and others.

The higher military educational institution environment is characterized by specific conditions which are conducive to formation and adaptation of novice teachers and suggest a number of stages to support professional development as a serviceman (including a scientific and pedagogical employee) $[12,316]$.

In addition to the cognitive-procedural component that means availability of essential knowledge, and efficientlyreflexive components that imply the availability of practical skills, the motivational component of the teachers readiness for educational activities is also important. The teacher self-assessment of his/her motivation for educational activities affects the results of the activities. Thus, one of the possible ways to achieve these results is a motivational interview.

Motivational interviewing (MI) is a strengths-based, clientcentered, and directive method for eliciting behavior change through conversation (T. J. Manthey, B. Knowles, D. Asher, and S. Wahab [13; 14]).

This problem was studied by D. Smith, M. Hohman, $\mathrm{S}$. Wahab, and T. Manthey, who formed the purpose of the study. According to their research, "As the evidence supporting MI has increased over time so has the demand for MI teaching and implementation support. Researchers, employers, and practitioners need to be able to define and measure the constituents of best teaching practices. Such efforts may improve the quality of MI training and aid the dissemination of this empirically supported treatment while safeguarding fidelity to the model. The purpose of this study was to develop and test a measure of studentreported MI training competency called the Evaluation of Motivational Interviewing Teaching (EMIT)" [15]. According to the results, the major contribution to the study is the initial development of internally consistent (i.e., factorial validity) measures of MI-Consistent and MIInconsistent teaching practices [15].

As officers, the prospective scientific-pedagogical employees of the National Academy of the National Guard of Ukraine do not have a degree in Pedagogy, and the Educational and Methodical Center places a large level of importance to the current issue. There is a Novice Teacher School at NANGU that will operate from the beginning of the new school year in accordance with the training curriculum 'The Staffing of the Educational Process at the HMEE' [16].

In addition, the advanced training course for pedagogical, scientific and scientific-pedagogical employees in order to improve the educational process has been finalized at NANGU. Moreover, the training curriculum has been developed [17] based on the MIA order No. 540 adopted on July 17, 2020 — "NANGU Training Volumes" [18]. From the beginning of the new school year the above mentioned training curriculum is to be implemented by the state order, which aims at improving teachers' professional competence and pedagogical skills. This training course is of great interest since it suggests a separate content module on interactive teaching strategies. On the phase of curriculum accreditation, the creation of conditions for infusing teachers to new forms and strategies of teaching and learning is studied, so that the experts have repeatedly noted the course as a positive practice for NANGU.

As the National Academy of the National Guard of Ukraine trains specialists in the specialties of Philology (035), Force support (254) and provides the NGU officers with advanced training in language communication, it is important to improve professional skills in teachers who teach foreign languages. For today, the advanced training curriculum for the foreign language teachers has been developed, and is to be implemented for the current school year [19].

The Academy has a wide range of opportunities for professional development. They include a free internship in all the NGU units, stable bonds and consistent cooperation with Kharkiv and Kyiv educational establishments.

Despite the fact that the HEE teachers are restricted from studying and doing internships abroad, during the academic year NANGU personnel improved their skills in Azerbaijan, Italy, Canada, Germany, Romania, France, Sweden, and Jamaica.

Prometheus, the Ukrainian educational platform of massive open online courses. provides many programs to improve one's skills within the development of the Internal Quality Ensuring System (IQES) in the High Educational Establishment [20].

The process of professional development is regulated by the Regulation on the Advanced Training for Teachers at the National Academy of the National Guard of Ukraine. The regulations were developed by the Educational and Methodical Center during the school year [21].

\section{RESULTS AND DISCUSSION}

The adoption of certain decisions in order to improve the professional skills of NANGU teachers comes from the results of the research.

Based on the analysis of modern literary sources, we have developed an experimental pedagogical curriculum. The purpose of the experiment is to test the effectiveness of pedagogical conditions for forming and developing readiness for educational activities in teachers of higher military educational institutions (HMEI) and prospective teachers of military units (MU).

The independent variables are the pedagogical conditions for developing readiness for educational activity in HMEI teachers and prospective MU teacher. The dependent variables are the level of readiness for educational activities among HMEI teachers and MU prospective teachers.

The participants of the experiment are students of the postgraduate course. Quantitative (age) or qualitative (gender) characteristics of the participants do not affect the 
observation process in this study [16], as applicants are usually of different ages, and the results obtained from the survey of respondents by gender in order to assess readiness for educational activities among HMEI teachers and MU prospective teachers are relatively the same.
It can therefore be assumed that there is no contradiction or error in representativeness between these characteristics of the general and sample populations. 230 people were involved in the experiment (Control Group (CG) - 150, Experimental Group (EG) - 80) (Table 1).

Table 1 HMEI teachers and prospective MU teachers who studied according to the training curriculum of the postgraduate education courses

\begin{tabular}{|l|r|r|r|}
\hline \multirow{2}{*}{ Training curriculum of the postgraduate education course } & \multicolumn{3}{|c|}{ Respondents } \\
\cline { 2 - 4 } & \multicolumn{1}{|c|}{ Total } & \multicolumn{1}{c|}{ Control Group } & \multicolumn{1}{c|}{ Experimental Group } \\
\hline Improving pedagogical skills and the educational process & 84 & 49 & 35 \\
\hline Teaching foreign languages strategies & 146 & 101 & 45 \\
\hline Total & 230 & 150 & 80 \\
\hline
\end{tabular}

Earlier, the NANGU teachers received advanced training in advanced pedagogical skills and educational process program at the Kharkiv National Air Force University named after I. Kozhedub. Over time, the Heads of the University announced that they would not be able to accept our applicants for such training. Our HEI decided to initiate an appropriate program. Therefore, we decided to conduct an experiment to find out the number of teachers who feel ready for educational activities before and after training following the previously outlined components of readiness (motivational-value, cognitive-procedural and efficientlyreflexive components). Moreover, we surveyed the teachers' preferences as potential applicants to complete the program.

Unlike Kharkiv National Air Force University (KhNAFU), in addition to the content modules "Actual problems of philosophy", "Actual problems of higher school pedagogy" and "Actual problems of higher school psychology", NANGU introduced "Interactive teaching methods" and "Strategic communication in the educational process". These courses focus on the motivational interview.

They are to form the pedagogical conditions. The unique point of the NANGU program is its practicum part - the period between the completion of teaching content modules and final exams is allocated for demo lessons that ae to be taught by each scientific-pedagogical employee, who studied the courses, in the presence of the training center representatives, course teachers and other scientificpedagogical employees. During the discussion of the demo lesson, the teacher must report to the staff of the department on the competencies he/she had gained upon the training and used them further when preparing and conducting this lesson. An excerpt from the minutes of the department meeting on the results of the discussion of the demo lesson is submitted for the exam. The selection of teachers for the course was completed.

According to the postgraduate education curriculum, 49 people at KhNAFU and 35 people at NANGU have taken a training course on the advancement of pedagogical skills and the educational process in recent years.

Since October 2016, the NANGU language department has been conducting intensive courses in foreign languages to train NGU personnel and assess their level of knowledge following the NATO STANAG 6001. This process ensures the participation of officers in international activities and international operations aimed at supporting peace and security under the United Nations, promoting foreign language education among officers and selecting prospective foreign language teachers for the military units. Thus, by July 2019, 88 and 13 officers were given training in English and in French respectively.

However, according to the survey results obtained for both employers (MHQ NGU) and the applicants (trainees) themselves, the officers are not ready to teach foreign languages in the MU.

In July 2019, NANGU held a course on improving the school language training process for English teachers. This course was held for the first time in cooperation with representatives of the Bureau of International Language Coordination (BILC).

Two BILC representatives visited the National Academy of the National Guard of Ukraine to conduct the training course - Ausra Narbutiene, the Head of the Language Testing Department of the Lithuanian Armed Forces Training Command and Michael Campbell, Curriculum Manager of the European Language Training Partnership Center in Garmisch-Partenkirchen.

During the first training day, the course participants discussed the STANAG 6001 components, levels and types of testing. The main attention was paid to working out practical tasks related to one of the STANAG 6001 components - speaking.

During the classes, the BILC representatives and the NANGU teachers discussed the issues of preparation for testing, various approaches to improving the communication skills of applicants and the process of their assessment.

The participants practiced exercises to assess the level of communication skills of applicants. BILC specialists showed the teachers three different types of interviews, after which the latter determined the communicative level of the speaker according to STANAG 6001.

The representatives of the Bureau of International Language Coordination noted the high motivation and professionalism of NANGU teachers.

In accordance with the BILC recommendations, the duration of intensive courses of foreign languages was extended from three (432 hours) to four months (540 
hours) for more effective foreign language training by the servicemen.

Due to the use of modern technical tools in the learning process, a better and more interactive presentation of the material was achieved.

104 hours of study time were allocated for the practical component. The groups held conferences, binary classes, presentations, round tables, interactive games, blitz quizzes, and online classes.

In addition, the students had the opportunity to practice in conducting classes with their study group and cadets using the materials developed for the intensive courses.

One of the conditions for teachers to make better preparations for their classes was the presence of tutors (native speakers) and the use of information and technology forms of learning (distance learning).

All these changes to the program are the pedagogical conditions. The pedagogical conditions were also tested through conducting a pedagogical experiment. From July 2019 , according to the updated curriculum on new methods of teaching foreign languages 35 and 10 officers were trained in English and French correspondingly.

Assessing the readiness of HMEI teachers and prospective MU teachers for educational activities was to diagnose the application of the selected teaching strategies. The characteristic of the applicant (a sign) is the results of the tasks solved by him. The results of the experiment were obtained on an ordinal scale.

After studying the state of readiness developed in HMEI teachers and prospective MU teachers, the results for the control phase of the experiment were obtained (Tables 2 , 3). According to the calculations performed in the computer program "Statistics in Pedagogy" [22], the following data were obtained.

Table 2 Dynamics of the levels of the development of the HMEI teachers' readiness for educational activity

\begin{tabular}{|c|c|c|c|c|c|c|c|}
\hline \multirow[b]{3}{*}{ Component } & \multirow[b]{3}{*}{ Level } & \multicolumn{6}{|c|}{ Respondents } \\
\hline & & \multicolumn{3}{|c|}{ Control group (total of 49) } & \multicolumn{3}{|c|}{ Experimental group (total of 35) } \\
\hline & & $\begin{array}{l}\text { Prior to the } \\
\text { experiment } \\
(p p l / \%)\end{array}$ & $\begin{array}{c}\text { After the } \\
\text { experiment } \\
(\text { ppl /\%) }\end{array}$ & $\begin{array}{c}\text { Dynamics } \\
(\mathrm{ppl} / \%)\end{array}$ & $\begin{array}{l}\text { Prior to the } \\
\text { experiment } \\
(p p l / \%)\end{array}$ & $\begin{array}{c}\text { After the } \\
\text { experiment } \\
(\text { ppl /\%) }\end{array}$ & $\begin{array}{c}\text { Dynamics } \\
(\text { ppl /\%) }\end{array}$ \\
\hline \multirow{3}{*}{ Motivational } & Low & $25 / 51$ & $19 / 39$ & $-6 /-12$ & $15 / 43$ & $6 / 17$ & $-9 /-26$ \\
\hline & Mid & $9 / 18$ & $11 / 22$ & $2 / 4$ & $6 / 17$ & $5 / 14$ & $-1 /-3$ \\
\hline & High & $15 / 31$ & $19 / 39$ & $4 / 8$ & $14 / 40$ & $24 / 69$ & $10 / 29$ \\
\hline \multirow{3}{*}{$\begin{array}{l}\text { Cognitive- } \\
\text { procedural }\end{array}$} & Low & $18 / 37$ & $14 / 29$ & $-4 /-8$ & $10 / 29$ & $7 / 20$ & $-3 /-9$ \\
\hline & Mid & $16 / 32$ & $18 / 37$ & $2 / 5$ & $13 / 37$ & $6 / 17$ & $-7 /-10$ \\
\hline & High & $15 / 31$ & $17 / 34$ & $2 / 3$ & $12 / 34$ & $22 / 63$ & $10 / 19$ \\
\hline \multirow{3}{*}{$\begin{array}{l}\text { Efficiently- } \\
\text { reflexive }\end{array}$} & Low & $26 / 53$ & $21 / 43$ & $-5 /-10$ & $15 / 43$ & $5 / 14$ & $-10 /-29$ \\
\hline & Mid & $12 / 25$ & $13 / 26$ & $1 / 1$ & $6 / 17$ & $8 / 23$ & $2 / 6$ \\
\hline & High & $11 / 22$ & $15 / 31$ & $4 / 9$ & $14 / 40$ & $22 / 63$ & $8 / 23$ \\
\hline
\end{tabular}

The comparison of data for the control group (CG) and experimental group (EG) which were obtained after the experiment on the formation and development of readiness for educational activities in HMEI teachers resulted in the following figures: the motivational component determined that the empirical value of the criterion $\chi 2$ equals to 7.4654 . According to the cognitive-procedural component, the empirical value of the criterion $\chi^{2}$ has been determined to equal to 6.8308 . In addition, for the efficiently-reflexive component, the empirical value of the criterion $\chi^{2}$ equals to 10.3141. The critical value equals to 5,991 . The reliability of the differences in the characteristics of the compared groups comprises 95\%. A statistically substantiated conclusion is made that both groups are statistically different. 
Table 3 Dynamic of the development of readiness for foreign languages training in HMEI teachers and prospective MU teachers

\begin{tabular}{|c|c|c|c|c|c|c|c|}
\hline \multirow[b]{3}{*}{ Component } & \multirow[b]{3}{*}{ Level } & \multicolumn{6}{|c|}{ Respondents } \\
\hline & & \multicolumn{3}{|c|}{ Control group (total of 101) } & \multicolumn{3}{|c|}{ Experimental group (total of 45) } \\
\hline & & $\begin{array}{c}\text { Prior to the } \\
\text { experiment } \\
\text { (ppl /\%) }\end{array}$ & $\begin{array}{l}\text { After the } \\
\text { experiment } \\
\text { (ppl/\%) }\end{array}$ & $\begin{array}{c}\text { Dynamics } \\
\text { (ppl/\%) }\end{array}$ & $\begin{array}{l}\text { Prior to the } \\
\text { experiment } \\
(\text { ppl /\%) }\end{array}$ & $\begin{array}{l}\text { After the } \\
\text { experiment } \\
\text { (ppl/\%) }\end{array}$ & $\begin{array}{c}\text { Dynamics } \\
\text { (ppl/\%) }\end{array}$ \\
\hline \multirow{3}{*}{ Motivational } & Low & $52 / 51$ & $38 / 37$ & $-14 /-14$ & $19 / 42$ & $9 / 20$ & $-10 /-12$ \\
\hline & Mid & $19 / 19$ & $22 / 22$ & $3 / 3$ & $9 / 20$ & $8 / 18$ & $-1 /-2$ \\
\hline & High & $30 / 30$ & $41 / 41$ & $11 / 11$ & $17 / 38$ & $28 / 62$ & $11 / 14$ \\
\hline \multirow{3}{*}{$\begin{array}{l}\text { Cognitive- } \\
\text { procedural }\end{array}$} & Low & $39 / 38$ & $31 / 31$ & $-8 /-7$ & $16 / 36$ & $8 / 18$ & $-8 /-18$ \\
\hline & Mid & $32 / 32$ & $36 / 35$ & $4 / 3$ & $14 / 31$ & $10 / 22$ & $-4 /-9$ \\
\hline & High & $30 / 30$ & $34 / 34$ & $4 / 4$ & $15 / 33$ & $27 / 60$ & $12 / 27$ \\
\hline \multirow{3}{*}{$\begin{array}{l}\text { Efficiently- } \\
\text { reflexive }\end{array}$} & Low & $53 / 52$ & $42 / 41$ & $-11 /-11$ & $17 / 38$ & $7 / 16$ & $-10 /-12$ \\
\hline & Mid & $25 / 25$ & $26 / 26$ & $1 / 1$ & $9 / 20$ & $9 / 20$ & $0 / 0$ \\
\hline & High & $23 / 23$ & $33 / 33$ & $10 / 10$ & $19 / 42$ & $29 / 64$ & $10 / 12$ \\
\hline
\end{tabular}

The research results for the levels of developed readiness for educational activity in HMEI teachers are presented in Table 2

The experimental data of a comparative analysis show an increase in the percentage of EG students compared to CG students with a high level of readiness for active duty and combat activities among future reserve officers with respect to the motivational component (by $21 \%$ ), cognitiveprocedural component (by 16\%), and efficiently-reflexive component (by 14\%).

On the completion of experiment, the comparative analysis of the two groups (HMEI teachers and prospective MU teachers) in terms of their developed readiness for teaching foreign languages gave the following results. The motivational component has determined that the empirical value of the criterion $\chi 2$ equals to 6.3277. According to the cognitive-procedural component, the empirical value of the criterion $\chi 2$ equals to 8.8917 . In addition, for the efficiently-reflexive component, the empirical value of the criterion $\chi 2$ equals to 14.1119 . The critical one equals to 5,991. The reliability of the differences in the characteristics of the compared groups comprises $95 \%$. A statistically substantiated conclusion is made that both groups are statistically different.

The EG and KG data obtained for the HMEI teachers and prospective MU teachers with respect to the development of their readiness for foreign language training are presented in Table 3.

A comparative analysis of the experimental data show an increase in the percentage of students from the experimental group compared to the one from control group with a high level of readiness for active duty and combat activities in future reserve officers with respect to the motivational component (by 3\%), cognitive-procedural component (by 23\%), and efficiently-reflexive component (by $2 \%$ ).

\section{CONCLUSION}

The current research reflects the NANGU experience in teacher advance training and the results of the pedagogical experiment on building and developing readiness for educational activities in teachers of higher military educational institutions and military units. The experiment involved 230 teachers who were split for study under two postgraduate education programs - (1) improvement of pedagogical skills and the educational process and (2) foreign language teaching strategies. The new pedagogical conditions for teaching under Program 1 were the updated content modules such as "Interactive teaching methods" and "Strategic communication in the educational process" and teaching a demo lesson, during the discussion of which the teacher must report to the staff of the department on the competencies he/she had gained upon the training and used them further when preparing and conducting this lesson. The new pedagogical conditions for studying under Program 2 encompass the extension of the course duration; the application of modern technical tools in the learning process; the practical component implementation; increase and diversification of interactive teaching methods; involvement of foreign language teachers among native speakers and the use of information and technology forms of learning (distance learning).

According to the results of the experiment, the EG teachers showed a higher level of readiness for educational activities.

However, the development dynamics of the HMEI teachers' readiness for educational activities in terms of motivational components differs significantly from the dynamics of the one displayed by HMEI teachers and prospective MU teachers with respect to foreign language training. According to the results of an additional questionnaire, the development dynamics of readiness for educational activities among the HMEI teachers turned out 
to be significantly influenced by the application of motivational interviews during the preparation process. Thus, our research has vital prospects for further development. In the future, we are planning to improve the quality of the learning process using distance learning strategies by placing focus on the appropriate teachers' training. It is also suggested implementing a motivational interview in the training course program for the HMEI teachers and prospective MU teachers of foreign languages.

\section{REFERENCES}

[1] Ukraine Education Act - 2145-VIII: Adopted on September 05, 2017. [URL: https://

zakon.rada.gov.ua/laws/show/2145-19], [in Ukrainian].

[2] A. Ye. Rezanovich (2002), Development of students readiness for organizational activities in a higher education institutions, Extended abstract of candidate's thesis, Magnitogorsk, 22 p. [in Russian].

[3] S. M. Wilson, D. L. Ball (1996), Helping Teachers Meet the Standards: New Challenges for Teacher Educators, The Elementary School Journal, 97, 2, pp. 121-138. DOI: https://doi.org/10.1086/461858

[4] J. C. Duncheon, J. Muñoz (2019), Examining Teacher Perspectives on College Readiness in an Early College High School Context, American Journal of Education, 125, 3, pp. 453-478. DOI: https://doi.org/10.1086/702731

[5] S. M. Khatuntseva (2007), Adaptation of a beginner teacher to a professional-pedagogical activity in a higher education institution, Berdyan. State. Ped. Univ. Donetsk, 175 p. [in Ukrainian].

[6] S. O. Shara (2013), Professional and pedagogical adaptation of young teachers of higher educational establishments of non pedagogical profile, Extended abstract of candidate's thesis, Pereyaslav-Khmelnitsky, 20 p. [in Ukrainian].

[7] T. D. Fedirchyk (2016), Theoretical and methodological foundations of the development of pedagogical professionalism of a young teacher of higher education in the process of scientific and pedagogical activity, Extended abstract of Doctor's thesis. Kyiv, 40 p. [in Ukrainian].

[8] V. V. Yehorova (2014), Analysis, current state and prospects of development of the systematic work of the higher education institution as a center of advanced training of scientific and pedagogical workers, Collection of scientific works of Khmelnitsky Institute of Social Technologies, University of Ukraine, 1, pp. 34-40. [in Ukrainian].

[9] V. M. Moroz (2014), Mechanism of organization of advanced training of scientific and pedagogical workers as an object of state management of quality of education, Scientific notes of the Institute of Legislation of the Verkhovna Rada of Ukraine, 3, pp. 107-113. [in Ukrainian].

[10] M. Vanderburg, D. Stephens (2010), The Impact of Literacy Coaches: What Teachers Value and How Teachers Change, The Elementary School Journal, 111, 1, pp. 141-163. DOI: https://doi.org/10.1086/653473

[11] M. Medvid, I. Chernichenko, Yu. Medvid, V. Dem'yanyshyn (2020), CMU resolution 800-2019 implementation adopted on August 21, 2019 "Some issues on advanced training..." in the process of becoming a higher military educational institution novice teacher, Youth and Marcet, 1 (180), pp. 6-11. DOI: https://doi.org/10.24919/2308-4634.2020.195708

[12] M. M. Medvid (2015), Methodology of formation and development of human resources for use in combat service, Doctor's thesis, Kharkiv, 577 p. [in Ukrainian]

[13] T. J. Manthey, B. Knowles, D. Asher, \& S. Wahab, (2011), Strengths-based practice and motivational interviewing, Advances in Social Work, 12, pp. 126151.

[14] S. Wahab (2005), Motivational interviewing and social work practice, Journal of Social Work, 5 (1), pp 45-60. DOI:

https://doi.org/10.1177/1468017305051365

[15] D. Smith, M. Hohman, S. Wahab, T. Manthey (2005), Student-Perceived Quality of Motivational Interviewing Training: A Factor-Analytic Study, Journal of the Society for Social Work and Research, 8, 1. DOI: https://doi.org/10.1086/690636

[16] The staffing of the educational process at the HMEE, Novice Teacher School the educational and professional program, $20 \mathrm{p}$. [URL:

http://nangu.edu.ua/uploads/files/documenty/osvita/OPP _SHVP.pdf], [in Ukrainian].

[17] The pedagogical, scientific and scientificpedagogical employees advanced training in the field of educational process improvement, The educational and professional program, $31 \mathrm{p}$. [URL:

http://nangu.edu.ua/uploads/files/documenty/osvita/OPP _NPP_2020.pdf], [in Ukrainian]. 
[18] Training of the personnel at the NA NGU. (NGU 540, adopted on July 17, 2020). 7 p. K: MIA pf Ukraine [in Ukrainian].

[19] The methodology of the English language training at NGU, The educational and professional program. 25 p. [URL: https://cutt.ly/cfeW2Hv], [in Ukrainian].

[20] Prometheus [URL: https://prometheus.org.ua/], [in Ukrainian].
[21] M. Medvid, I. Chernichenko, and others, under S. Sokolovskii general edition, Regulations on the advanced training of pedagogical, scientific and scientific-pedagogical employees at the National Academy of the National Guard of Ukraine, $82 \mathrm{p}$. [URL: https://cutt.ly/rfqVRjg], [in Ukrainian].

[22] Application "Statistics in pedagogy" URL: http://www.mtas.ru/uploads/stat.zip [in Russian]. 